\title{
Muscle Cell Differentiation Is Associated with Increased Insulin Receptor Biosynthesis and Messenger RNA Levels
}

\author{
A. Brunetti, B. A. Maddux, K. Y. Wong, and I. D. Goldfine \\ Cell Biology Laboratory and Department of Medicine, Mount Zion Hospital and Medical Center, San Francisco, California 94115; \\ and Departments of Medicine and Physiology, University of California, San Francisco, California 94143
}

\begin{abstract}
Muscle is a major tissue for insulin action. To study the effect of muscle differentiation on insulin receptors, we employed cultured mouse muscle $\mathrm{BC} 3 \mathrm{H}-1$ and $\mathrm{C} 2$ cells. In both cell lines differentiation from myoblasts to myocytes was associated with a 5-10-fold increase in specific ${ }^{125}$ I-insulin binding to intact cells. When ${ }^{125}$ I-insulin binding was carried out on solubilized myocytes and myoblasts, ${ }^{125} \mathrm{I}$-insulin binding to myoblasts was low. After differentiation the number of insulin receptors increased 5-10-fold. In contrast to insulin binding, insulin growth factor I receptor binding was elevated in myoblasts and was decreased by $\mathbf{5 0 \%}$ in myocytes. Specific radioimmunoassay of the insulin receptor indicated that the increase in insulin binding to myocytes was due to an increase in insulin receptor content. Studies employing [ ${ }^{35}$ S]methionine indicated that this increase in insulin-binding sites reflected an increase in insulin receptor biosynthesis. To study insulin receptor gene expression, myoblast and myocyte mRNA was isolated and analyzed on Northern and slot blots. Differentiation from myoblasts to myocytes was accompanied by a 5-10fold increase in insulin receptor mRNA. These studies demonstrate, therefore that differentiation in muscle cells is accompanied by increased insulin receptor biosynthesis and gene expression.
\end{abstract}

\section{Introduction}

Muscle is a major target tissue for insulin action. In muscle, insulin regulates the transport of glucose which leads to major changes in blood glucose concentrations (1). In addition, in muscle, insulin regulates a variety of other functions including transport of amino acids, ions, and nucleotides; electrical potential; protein synthesis and degradation; and RNA metabo$\operatorname{lism}(2)$.

The initial interaction of insulin with muscle and other target cells is via a receptor located in the plasma membrane (3-6). This receptor serves a role both in directing insulin to specific target tissues and in initiating the response of tissues to the hormone. The insulin receptor is a tetrameric glycoprotein that is composed of two extracellular $\alpha$ subunits (130 kD) that bind the hormone and two transmembrane $\beta$ subunits (95 kD) that contain tyrosine kinase activity in their intracellular domains (3-6). One $\alpha$ and one $\beta$ subunit are derived from a common precursor protein that has a minimum molecular mass of $153 \mathrm{kD}$ as derived from cDNA analysis $(7,8)$.

Received for publication 8 April 1988 and in revised form 25 July 1988.

J. Clin. Invest.

(C) The American Society for Clinical Investigation, Inc.

0021-9738/89/01/0192/07 \$2.00

Volume 83, January $1989,192-198$
In a variety of tissues the insulin receptor has been demonstrated to be under the regulation of hormones, metabolites, and differentiation $(3-6,9)$. Studies in adult muscle, however, have been limited by two technical difficulties. First, insulin receptor protein and mRNA levels in muscle are relatively low compared to other major insulin responsive tissues such as liver (10). Secondly, it is relatively difficult to subfractionate muscle in order to obtain receptor-rich plasma membrane fractions (11).

Cultured mouse and rat cell lines have been employed in order to study the in vitro regulation of muscle insulin receptors $(12,13)$. These cells grow as undifferentiated myoblasts when kept at low densities in media with high serum concentrations (14-16). However, when confluent cells are grown in media with low serum concentrations, the cells morphologically differentiate into myocytes (14-17). In addition to morphologic changes, there are changes in the content of muscle specific proteins $(18,19)$. Concomitant with differentiation into myocytes, there is also an increase in insulin binding to its receptor $(12,13)$.

BC3H-1 cultured mouse muscle cells have been studied extensively and show a 5-10-fold increase in insulin receptors when myoblasts differentiate into nonfusing myocytes (12). In myocytes there are enhanced effects of insulin on the regulation of several biological functions including glucose and amino acid transport, protein kinase activity, and phospholipid turnover $(12,20,21)$. The mechanism that accounts for the increased binding of insulin to differentiated $\mathrm{BC} 3 \mathrm{H}-1$ cells has not previously been elucidated.

In the present study we measured insulin receptor content by ligand binding and radioimmunoassay studies. Moreover, we measured insulin receptor biosynthesis and insulin receptor mRNA content. The data indicate that differentiation in $\mathrm{BC} 3 \mathrm{H}-1$ cells is accompanied by increased insulin receptor mRNA levels and increased receptor biosynthesis. Similar data were also obtained in $\mathrm{C} 2$ cultured muscle cells that differentiate into fusing myocytes (19).

\section{Methods}

\section{Chemicals}

The following chemicals were purchased: bacitracin, Hepes, and phenylmethylsulfonyl fluoride from Sigma Chemical Co., St. Louis, MO; bovine plasma albumin (fraction V) was from Reheis, Chicago, IL; ${ }^{125}$ I-labeled insulin and insulin growth factor I (IGF-I), ${ }^{1}$ and $\left[{ }^{35} \mathrm{~S}\right]-$ methionine from New England Nuclear, Boston, MA; porcine insulin from Elanco Products, Indianapolis, IN; Bio-Rad protein assay reagent, dithiothreitol, and molecular weight markers from Bio-Rad Laboratories, Richmond, CA; IgG Sorb (protein A) from Enzyme Center Inc., Boston, MA; Dulbecco's modified Eagle's medium (DME H-21) with minimal Eagle's medium amino acid supplement, with and

1. Abbreviations used in this paper: IGF-I, insulin growth factor I. 
without methionine, penicillin, streptomycin, amphotericin B, fetal bovine serum (FBS), and trypsin from the Cell Culture Facility, University of California, San Francisco, CA; tissue culture flasks and dishes from both Falcon Labware, Los Angeles, CA and Lux tissue culture dishes from Miles Laboratories, Inc., Naperville, IL; and IGF-I from Amgen, Thousand Oaks, CA.

Insulin receptor cDNA probes were a gift from Dr. G. I. Bell (University of Chicago). Ribosomal RNA gene pDF15 was a gift from Dr. A. P. Bollon (Westley Institute of Molecular Medicine). Antireceptor antiserum B-8 was a gift of Dr. S. I. Taylor (National Institutes of Health), and antireceptor antiserum Bd was a gift of Dr. G. Boden (Temple University).

\section{Cell culture}

The $\mathrm{BC} 3 \mathrm{H}-1$ and $\mathrm{C} 2$ mouse muscle cells were routinely grown in DME H-21 with $20 \%$ FBS. For experiments, cells were plated at an initial density of $6 \times 10^{3}$ cells $/ \mathrm{cm}^{2}$ in either $75-\mathrm{cm}^{2}$ tissue culture flasks or 35-mm tissue culture dishes. To initiate differentiation, the media containing 20\% FBS was removed on day 3 and replaced with media containing $1 \%$ FBS. The cells were then cultured for up to $16 \mathrm{~d}$ and the media changed every $3 \mathrm{~d}$. For experiments with undifferentiated $\mathrm{BC} 3 \mathrm{H}-1$ and $\mathrm{C} 2$ myoblasts, cells were plated in a similar manner and used only after $3 \mathrm{~d}$ in culture with $20 \%$ FBS.

Cell number was determined after cell dissociation with $0.25 \%$ trypsin and $0.5 \%$ EDTA at $37^{\circ} \mathrm{C}$.

\section{Hormone binding assays}

${ }^{125}$ I-insulin and ${ }^{125}$ I-IGF-I binding to intact cells. At the indicated times, cells attached to $35-\mathrm{mm}$ tissue dishes were rinsed with $3 \mathrm{ml}$ of binding buffer containing $120 \mathrm{mM} \mathrm{NaCl}, 1.2 \mathrm{mM} \mathrm{MgSO}_{4}, 15 \mathrm{mM} \mathrm{Na}$ acetate, $2.5 \mathrm{mM} \mathrm{KCl}, 10 \mathrm{mM}$ glucose, $1 \mathrm{mM}$ EDTA, $1 \%$ bovine serum albumin, and $100 \mathrm{mM}$ Hepes, $\mathrm{pH} 7.6$, and incubated in $2 \mathrm{ml}$ of the same buffer containing $40 \mathrm{pM}^{125} \mathrm{I}$-insulin for $20 \mathrm{~h}$ at $4^{\circ} \mathrm{C}$ (12). The incubation medium was then removed, the monolayers were washed twice, the cells were lysed with $0.1 \mathrm{M} \mathrm{NaOH}$, and the radioactivity associated with the cell lysate was measured in a gamma-scintillation counter (Beckman Instruments, Inc., Palo Alto, CA). Binding was corrected for nonspecific ${ }^{125}$ I-insulin binding ( $<5 \%$ of total) as determined in the presence of an excess $(1 \mu \mathrm{M})$ of unlabeled insulin. Specific ${ }^{125} \mathrm{I}$-IGF-I binding was carried out in the same manner with $10 \mathrm{pM}$ labeled hormone and $100 \mu \mathrm{M}$ unlabeled hormone.

${ }^{125}$ I-insulin and ${ }^{125}$ I-IGF-I binding to solubilized myoblasts and myocytes. Cells were gently scraped from the surface of the flasks and solubilized with $0.4 \%$ Triton $X-100$ for 30 min at $4^{\circ} \mathrm{C}(22)$. Solubilized insulin and IGF-I receptors from $\mathrm{BC} 3 \mathrm{H}-1$ cells were precipitated and concentrated by the addition of $30 \%$ polyethylene glycol at $4^{\circ} \mathrm{C}$. The pellet was reconstituted in binding buffer with $0.02 \%$ Triton X-100 at a concentration of $560 \mu \mathrm{g}$ cell protein $/ \mathrm{ml}$. Solubilized receptor binding from myoblasts and myocytes was assayed in triplicate by adding either $40 \mathrm{pM}$ of either ${ }^{125}$ I-insulin or $10 \mathrm{pM}{ }^{125} \mathrm{I}$-IGF-I to solubilized receptors in binding buffer with $0.02 \%$ Triton X-100 in the absence or presence of unlabeled hormones. The binding reaction was terminated after $20 \mathrm{~h}$ of incubation at $4^{\circ} \mathrm{C}$ by adding $150 \mu \mathrm{l}$ of $30 \%$ polyethylene glycol and centrifuging the mixture at $11,000 \mathrm{~g}$ for $3 \mathrm{~min}$. In this manner the free ${ }^{125} \mathrm{I}$-ligands were separated from receptor-bound ligands present in the pellet. In all assays nonspecific binding was $<2 \%$ of total radioactivity.

\section{Insulin receptor radioimmunoassay}

This assay (23) employs purified human insulin receptor and high-affinity rabbit polyclonal antibody to the human insulin receptor (24). Highly purified human placental insulin receptor was obtained by sequential affinity chromatography with insulin receptor monoclonal antibody-agarose and wheat germ agglutinin-agarose (24). Purified human placental insulin receptor was labeled with ${ }^{125}$ I-Bolton Hunter reagent. The specific activity of the labeled insulin receptor preparations ranged from 2,000 to $3,000 \mathrm{Ci} / \mathrm{mmol}$. Unlabeled receptor $(0-20$ ng) or unknown sample and anti-insulin receptor antiserum were incubated for $16 \mathrm{~h}$ at $4^{\circ} \mathrm{C}$. ${ }^{125} \mathrm{I}$-labeled insulin receptor $(0.5 \mathrm{ng})$ was added for $24 \mathrm{~h}$ and then goat-rabbit $\gamma$-globulin serum was added. After $18 \mathrm{~h}$ at $4^{\circ} \mathrm{C}$, the tubes were centrifuged, the supernatants aspirated, and the radioactivity in the tubes was counted. To measure insulin receptor content in BC3H-1 myoblasts and myocytes, cells were solubilized in $50 \mathrm{mM}$ Hepes, $0.4 \%$ Triton X-100, $0.2 \mathrm{mM}$ phenylmethysulfonylfluoride, and $0.5 \mathrm{mg} / \mathrm{ml}$ bacitracin for $30 \mathrm{~min}$ at $4^{\circ} \mathrm{C}$. The lysate was then centrifuged for $3 \mathrm{~min}$ at $11,000 \mathrm{~g}$ and the supernatant was used for assay without further purification.

\section{Insulin receptor biosynthesis}

BC $3 \mathrm{H}-1$ and $\mathrm{C} 2$ cells were plated in $75-\mathrm{cm}^{2}$ flasks (Falcon Labware) at $6 \times 10^{3}$ cells $/ \mathrm{cm}^{2}$ in DME H-21 supplemented with $20 \%$ fetal bovine serum and differentiation induced as described above. To study insulin receptor biosynthesis, the flasks were washed twice in phosphate-buffered saline (PBS) and $5 \mathrm{ml}$ of methionine-free medium was added. The cells were labeled by the addition of $1 \mathrm{mCi}\left[{ }^{35} \mathrm{~S}\right]$ methionine. After $4 \mathrm{~h}$ at $37^{\circ} \mathrm{C}$, the monolayers were washed twice in PBS, and the cells were scraped off and solubilized for 60 min with Triton X-100 plus protease inhibitors (phenylmethylsulfonyl fluoride and bacitracin) (24). After solubilization the suspensions were centrifuged at $100,000 \mathrm{~g}$ for $60 \mathrm{~min}$ to remove insoluble components and the solubilized insulin receptors were partially purified by wheat-germ agglutinin chromatography. Labeled receptors were then immunoprecipitated using polyclonal antibodies, denatured under reducing conditions, and subjected to polyacrylamide gel electrophoresis (PAGE) and autoradiography (24).

\section{Preparation of RNA}

Total cellular RNA was extracted from both undifferentiated and differentiated $\mathrm{BC} 3 \mathrm{H}-1$ and $\mathrm{C} 2$ cells according to the guanidinium/thiocyanate/cesium chloride gradient method (25). Culture media was aspirated and the cells were removed by scraping into $10 \mathrm{ml}$ of PBS at $4^{\circ} \mathrm{C}$. Cell suspensions were centrifuged at $1,000 \mathrm{rpm}$ and cell pellets were resuspended in buffer containing $4.5 \mathrm{M}$ guanidinium thiocyanate, 50 mM EDTA (pH 7.8), 25 mM sodium citrate, pH 7.0, 0.1 mM 2-mercaptoethanol, and $2 \%$ lauryl sarcosine. The lysate was homogenized in a glass homogenizer for 10 strokes and cesium chloride was added at a concentration of $0.2 \mathrm{~g} / \mathrm{ml} .9 \mathrm{ml}$ of this solution was layered over $4.5 \mathrm{ml}$ of $5.7 \mathrm{M} \mathrm{CsCl}$ in a 13.5-ml polyallomer Quick-Seal tube (Beckman Instruments, Inc.). Sedimentation was performed in a type $70.1 \mathrm{Ti}$ rotor (Beckman Instruments, Inc.) at $70,000 \mathrm{rpm}$ for $4.5 \mathrm{~h}$ at $22^{\circ} \mathrm{C}$. After centrifugation, the RNA pellet was removed and dissolved in 10 $\mathrm{mM}$ Tris- $\mathrm{HCl}, \mathrm{pH}$ 7.6, 2 mM EDTA, 0.5\% SDS. Further purification was performed by extracting the sample with phenol and chloroform and then the RNA was precipitated with ethanol. Poly $(\mathrm{A})^{+}$RNA was isolated by oligo(dT)-cellulose chromatography according to the procedure described by Maniatis et al. (26).

\section{Slot blots and Northern transfers}

For Northern transfers poly $(A)^{+}$RNA was denatured in formaldehyde, subjected to electrophoresis in $1 \%$ agarose and transferred to nitrocellulose paper (27). For "slot blots" total RNA was denatured as described by Thomas (28) and various dilutions of RNA were immobilized to nitrocellulose using a Schleicher \& Schuell slot blot apparatus (Schleicher \& Shuell, Inc., Keene, NH). Yeast tRNA was added as a carrier to samples when the final RNA concentration was below 1 $\mu \mathrm{g} / \mathrm{ml}$.

\section{DNA labeling and RNA-DNA hybridization}

Two human insulin receptor cDNA probes (a gift from Dr. G. I. Bell, University of Chicago), spanning the entire open reading frame of the receptor and extending into the $3^{\prime}$-untranslated region (29), were labeled by nick translation (27) to a specific activity of $10^{9} \mathrm{cpm} / \mu \mathrm{g}$. The nitrocellulose filters were prehybridized and hybridized and washed as previously described (27). Probes for the $5^{\prime}$ portion of the rat $18 \mathrm{~S}$ ribosomal RNA gene (30) and for $\beta$-actin (31) were nick translated and also hybridized as described for the insulin receptor. 


\section{Results}

\section{Studies with $B C 3 H-1$ cells}

Increased insulin binding during $B C 3 H-1$ differentiation. When cells were kept at subconfluent densities and grown in $20 \%$ FBS, they maintained a typical myoblast appearance with a flat morphology and numerous small processes (18) (Fig. 1 $A$ ). When the cells were grown in $1 \%$ FBS and became confluent, they differentiated into myocytes with a typical spindly appearance (18) (Fig. $1 \mathrm{~B}$ ). Concomitant with this differentiation into myocytes there was an increase in ${ }^{125}$ I-insulin binding which was maximal at 14-16 d (Fig. $2 A$ ). When cells were placed into medium with $1 \%$ FBS, cell growth ceased and receptor binding increased. Myoblasts bound $0.25 \%$ of total radioactivity per $10^{6}$ cells; in contrast, myocytes bound $3.65 \pm 0.2 \%$ per $10^{6}$ cells $(n=3$, mean \pm SEM $)$.
Comparison of ${ }^{125}$ I-insulin and ${ }^{125}$ I-IGF-I binding in myocytes. The insulin receptor has structural similarity to the IGF-I receptor (32), and ${ }^{125}$ I-insulin can weakly bind to the IGF-I receptor. To determine whether the observed increase in ${ }^{125}$ I-insulin binding to myocytes was due to an increase in insulin receptors, insulin and IGF-I receptor binding were directly compared (Fig. $3 \mathrm{~A}$ ). In myoblasts, specific ${ }^{125}$ I-insulin binding was relatively low whereas specific ${ }^{125}$ I-IGF-I binding was elevated. When myoblasts differentiated into myocytes, ${ }^{125}$ I-IGF-I binding decreased whereas ${ }^{125}$ I-insulin binding increased.

To investigate the receptor specificity of ${ }^{125}$ I-insulin and ${ }^{125}$ I-IGF-I binding to $\mathrm{BC} 3 \mathrm{H}-1$ cells, competition-inhibition studies were carried out (Fig. 4). Specific ${ }^{125}$ I-insulin binding to mature myocytes was inhibited by unlabeled insulin one-halfmaximally at $\sim 1 \mathrm{nM}$; IGF-I only weakly interacted with the insulin receptor. One-half-maximal inhibition of insulin bind-
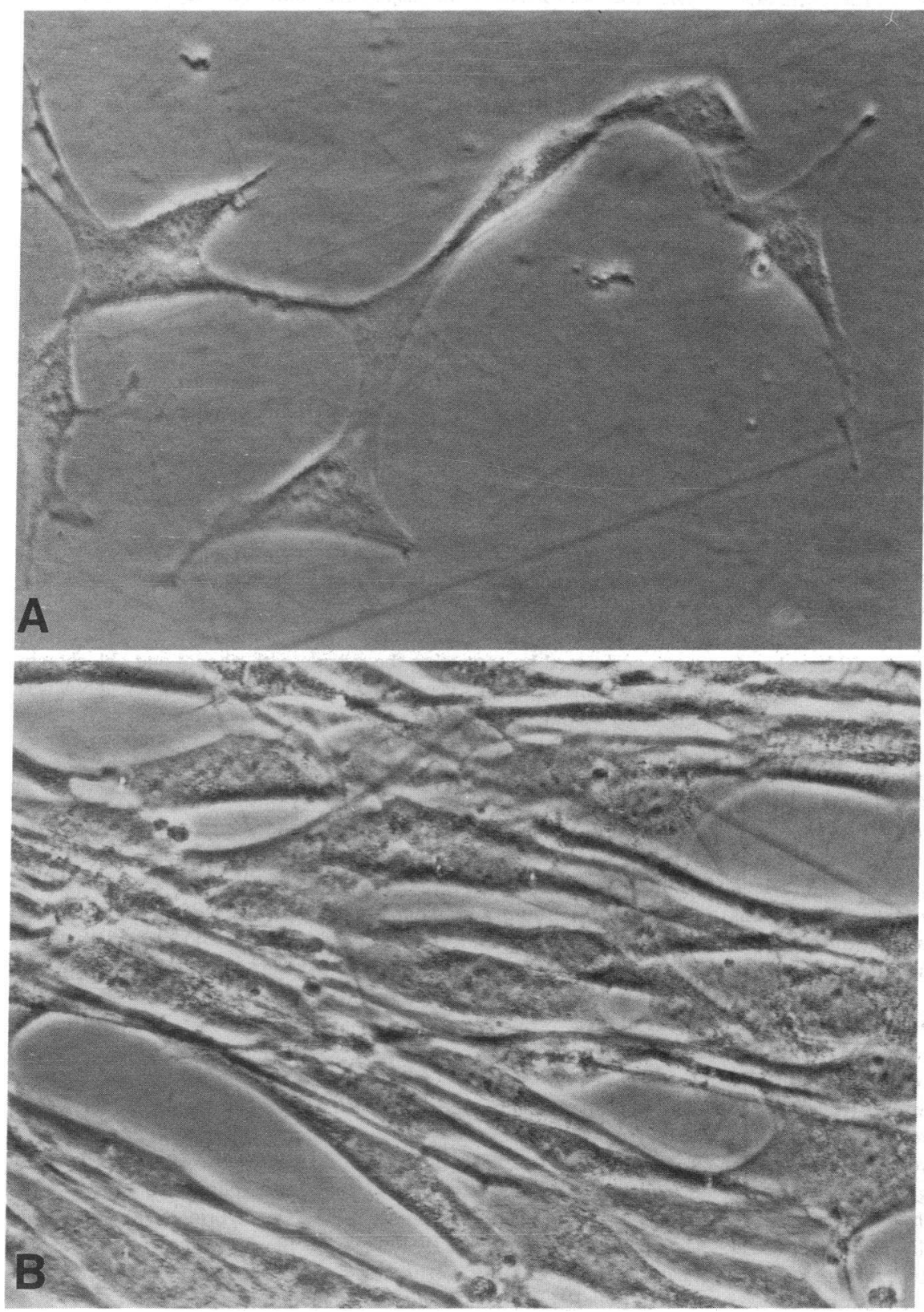

Figure 1. Morphological characteristics of BC3H-1 myoblasts and myocytes. Cells were placed in 35-mm tissue culture dishes at 6 $\times 10^{3}$ cells $/ \mathrm{cm}^{2}$ and cultured either in DME H-21 containing $20 \%$ FBS (to produce myoblasts) or DME H-21 containing 1\% FBS for $16 \mathrm{~d}$ (to produce myocytes). Photographs show the morphology of $(A)$ myoblasts and (B) myocytes. In $A$, the cells are separated and have a flat morphology with numerous small processes extending from the cell surface, whereas in $B$, the cells are at confluency and have a spindly morphology typical of differentiated myocytes. Cultures were photographed with an inverted Nikon phase microscope. $\times 40$. 

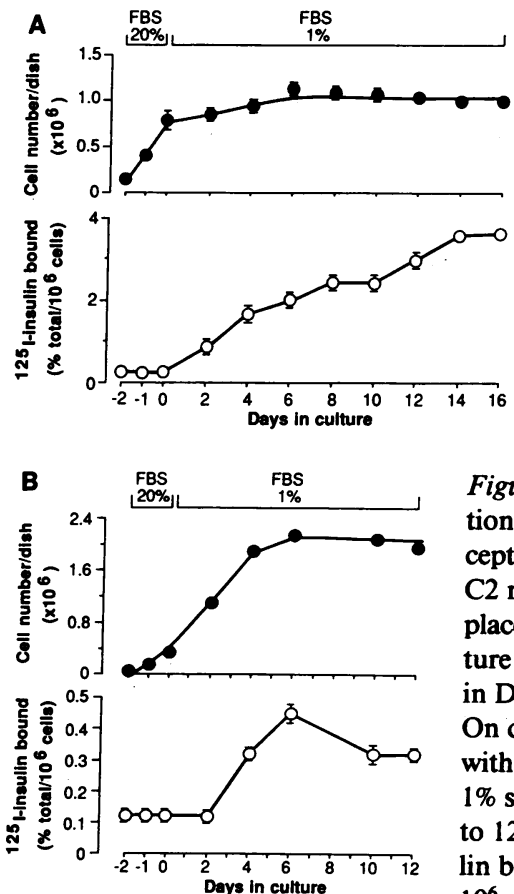

Figure 2. Effect of differentiation on insulin binding to receptors in $(A) \mathrm{BC} 3 \mathrm{H}-1$ and $(B)$ $\mathrm{C} 2$ muscle cells. Cells were placed on 35-mm tissue culture dishes at $6 \times 10^{3}$ cells $/ \mathrm{cm}^{2}$ in DME H-21 plus 20\% FBS. On day 0 , cells were incubated with medium that contained $1 \%$ serum and cultured for up to $12-16 \mathrm{~d}$. Specific ${ }^{125}$ I-insulin binding was expressed per $10^{6}$ cells. The cell number per dish as a function of time was determined by cell counting after dissociation with $0.25 \%$ trypsin and $0.5 \%$ EDTA at $37^{\circ} \mathrm{C}$. Values are the mean \pm SEM for three separate experiments.

ing occurred at $>100 \mathrm{nM}$ IGF-I. IGF-I inhibited the binding of labeled IGF-I to its receptor with a one-half-maximal effect occurring at $\sim 10 \mathrm{nM}$. Insulin was significantly less potent at inhibiting IGF-I binding.

Effect of differentiation on insulin receptor content of myocytes. The possibility was considered that ${ }^{125}$ I-insulin binding to receptors was increased in mature myocytes because differentiation either changed the affinity of the insulin receptor, or altered insulin receptor compartmentalization such that receptors that were previously unavailable for hormone binding in myoblasts became available for binding in myocytes. To study the effect of $\mathrm{BC} 3 \mathrm{H}-1$ differentiation on insulin receptor affinity, Scatchard analyses were performed (Fig. 5). Binding
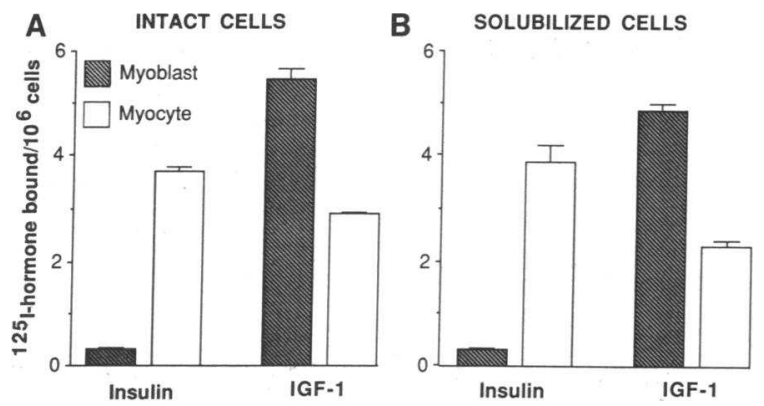

Figure 3. Comparison of insulin and IGF-I receptors in $\mathrm{BC} 3 \mathrm{H}-1$ myoblasts and myocytes. Cells were placed on $60-\mathrm{mm}$ tissue culture dishes and cultured for 3 or $16 \mathrm{~d}$ in DME H-21 supplemented with either $20 \%$ or $1 \%$ serum, respectively. Specific ${ }^{125}$ I-insulin and ${ }^{125} \mathrm{I}-$ IGF-I binding expressed per $10^{6}$ cells was determined in myoblasts and myocytes both $(A)$ in intact cells and $(B)$ with soluble receptors. Each bar is the mean \pm SEM of triplicate dishes of three separate experiments.
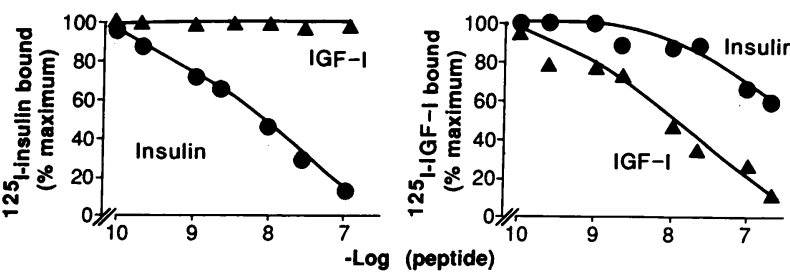

Figure 4. Specificity of insulin and IGF-I binding to their receptors in BC3H-1 myocytes. Cells were plated in $30-\mathrm{mm}$ tissue culture dishes and specific ${ }^{125} \mathrm{I}$-insulin and ${ }^{125} \mathrm{I}-\mathrm{IGF}-\mathrm{I}$ binding was then measured. Binding is expressed as a percentage of either maximal specific ${ }^{125} \mathrm{I}$-insulin or ${ }^{125} \mathrm{I}$-IGF-I binding. Each point is the mean of two separate experiments performed in triplicate.

of insulin to both myocytes and myoblasts was best fit by a two-site model. Differentiation increased the number of insulin receptors in both classes of binding sites (high affinity, $26,000 \pm 3,000$ binding sites per cell in myocytes, $1,000 \pm 120$ binding sites per cell in myoblasts; low affinity, $300,000 \pm 20,000$ binding sites per cell in myocytes, $20,000 \pm 2,000$ binding sites per cell in myoblasts). In contrast, affinity was not markedly altered (high affinity $0.28 \pm 0.06 \mathrm{nM}$ in myocytes, $0.25 \pm 0.09 \mathrm{nM}$ in myoblasts; low affinity $56.6 \pm 15$ $\mathrm{nM}$ in myocytes, $18.8 \pm 4.72 \mathrm{nM}$ in myoblasts).

To measure total cellular insulin binding sites, myocytes and myoblasts were solubilized and ${ }^{125} \mathrm{I}$-insulin binding was carried out on solubilized fractions (Fig. 3 B). Insulin binding to solubilized myoblasts was low and very similar to that of intact myoblasts. After differentiation, there was a 5-10-fold increase in the binding of ${ }^{125} \mathrm{I}$-insulin to solubilized myocytes. For comparison ${ }^{125} \mathrm{I}$-IGF-I binding was studied in solubilized cells. IGF-I binding was higher in myoblasts than in myocytes.

An alternative approach to measuring insulin receptor content was carried out by using a recently described radioimmunoassay of the insulin receptor (23). Solubilized extracts of myocytes were sevenfold more potent in displacing ${ }^{125}$ I-insulin receptor binding from the antibody than were solubilized extracts of myoblasts (Fig. 6). By radioimmunoassay it was estimated that myoblasts had $\sim 1 \mathrm{ng}$ of receptors per $10^{6}$ cells whereas mature myocytes had $7 \mathrm{ng}$ of receptors per $10^{6}$ cells.

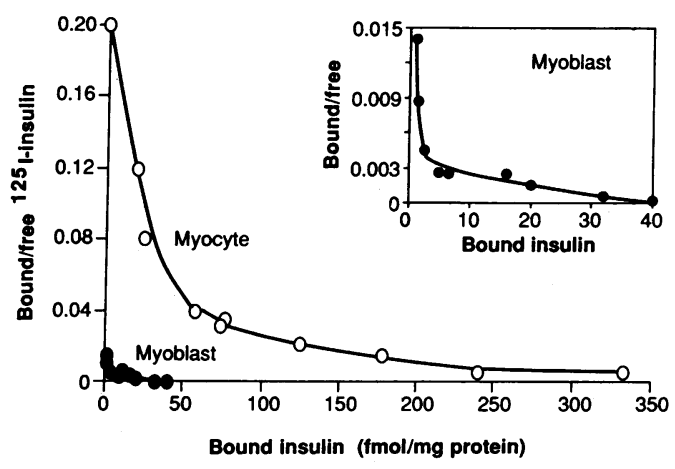

Figure 5. Scatchard plot of insulin binding to $\mathrm{BC} 3 \mathrm{H}-1$ myoblasts and myocytes. Specific ${ }^{125}$ I-insulin binding was measured, in the presence of increasing concentrations of insulin (to $1 \mu \mathrm{M}$ ). Each point is the mean \pm SEM of three separate experiments. Inset shows the binding data for myoblasts with an expanded scale. 


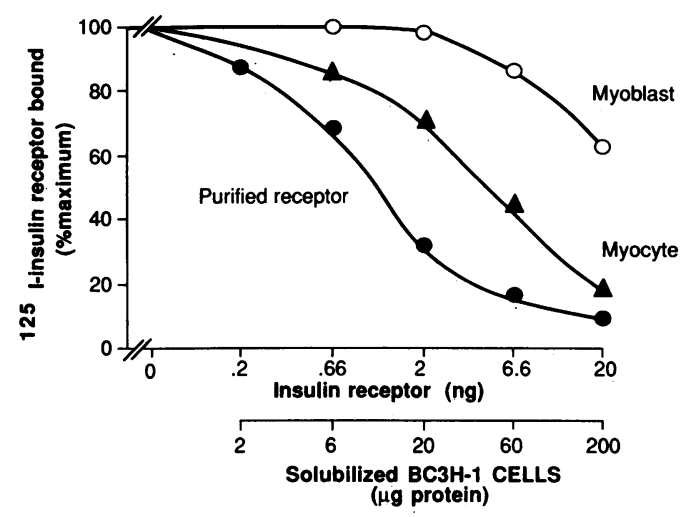

Figure 6. Insulin receptor radioimmunoassay in myoblasts and BC3H-1 myocytes. Ability of increasing concentrations of solubilized mouse muscle insulin receptors to compete with labeled insulin receptor for antireceptor antibody. (b) Insulin receptor standard, (O) myoblasts, ( $\Delta$ ) myocytes. A representative of three experiments is shown.

Insulin receptor biosynthesis. To study whether the increase in insulin receptor content was due to a change in receptor biosynthesis, labeling studies were carried out with $\left[{ }^{35} S\right]$ methionine. In these studies myoblasts and myocytes were labeled for $4 \mathrm{~h}$ with $\left[{ }^{35} \mathrm{~S}\right]$ methionine, the cells were solubilized, and the insulin receptor was immunoprecipitated with two potent polyclonal antireceptor antisera. Studies with both antisera indicated that differentiation was associated with a marked increase in the biosynthesis of the receptor $\alpha$ and $\beta$ subunits (135 and $95 \mathrm{kD}$, respectively) (Fig. $7 A$ ).

Insulin receptor $m R N A$ levels. To determine whether the increase in insulin receptor biosynthesis was associated with an increase in insulin receptor mRNA levels, slot blot and Northern blot analyses were carried out. Total RNA was extracted from myoblasts and myocytes and slot blotted, and the filters probed with labeled insulin receptor cDNA (Fig. $8 \mathrm{~A}$ ). Differentiation was associated with an approximately sixfold increase in insulin receptor mRNA content. Other filters were also probed with a DNA probe for the $18 \mathrm{~S}$ ribosomal RNA. As previously reported, differentiation was associated with a decrease in ribosomal RNA content (Fig. 8 B) $(14,17)$.
Insulin receptor mRNA consists of several species of different molecular sizes $(7,8,10,27)$. To determine whether differentiation was associated with qualitative difference in insulin receptor mRNA, poly $(A)^{+}$RNA was prepared from myoblasts and myocytes. The poly $(\mathrm{A})^{+}$RNA was then subjected to agarose gel electrophoresis followed by transfer to nitrocellular filters. The filters were then probed with labeled insulin receptor cDNA. In the BC3H-1 cells, two major bands were seen on autoradiography representing the two major species of insulin receptor mRNA at 7.0 and 9.5 kilobases (Fig. 9). Differentiation into myocytes was associated with a significant increase in both species. In contrast, a probe for $\beta$ actin, a protein known to decrease with muscle differentiation (33), showed a decrease in mRNA levels (data not shown).

\section{Studies with $C 2$ cells}

$\mathrm{C} 2$ myoblasts, unlike $\mathrm{BC} 3 \mathrm{H}-1$ myoblasts, fuse when they differentiate (19). In these cells, when the media was changed from $20 \%$ FBS to $1 \%$ FBS the cells differentiated. With differentiation insulin binding increased from $\sim 0.12 \pm 0.01 \%$ of total radioactivity per $10^{6}$ cells $(n=3$, mean \pm SEM) to approximately $0.45 \pm 0.03 \%$ (Fig. $2 \mathrm{~B}$ ). In contrast to $\mathrm{BC} 3 \mathrm{H}-1$ cells, however, $\mathrm{C} 2$ cells continued to grow for several days in $1 \%$ FBS. Specific ${ }^{125} \mathrm{I}$-insulin binding for $\mathrm{C} 2$ cells was typically $10-15 \%$ that of $\mathrm{BC} 3 \mathrm{H}-1$ cells.

In the $\mathrm{C} 2$ cells, as in $\mathrm{BC} 3 \mathrm{H}-1$ cells, there was an increase in insulin receptor biosynthesis as determined by $\left[{ }^{35} \mathrm{~S}\right]-$ methionine labeling studies (Fig. 7 B). Furthermore, $C 2$ insulin receptor mRNA levels, as determined by slot blot analysis, increased after differentiation (Fig. $8 \mathrm{~B}$ ).

\section{Discussion}

In the present study we have employed two lines of cultured muscle cells, $\mathrm{BC} 3 \mathrm{H}-1$ and $\mathrm{C} 2$, to study the effect of muscle differentiation on insulin receptor expression. In both cell lines, myoblasts differentiated into myocytes upon reaching confluence and having the serum concentration reduced from $20 \%$ to $1 \%$. BC3H-1 cells are derived from a nitrosoethylureainduced brain neoplasm (18) and the exact cell of origin is unknown. These cells have the major morphological properties of smooth muscle cells but also have some properties of

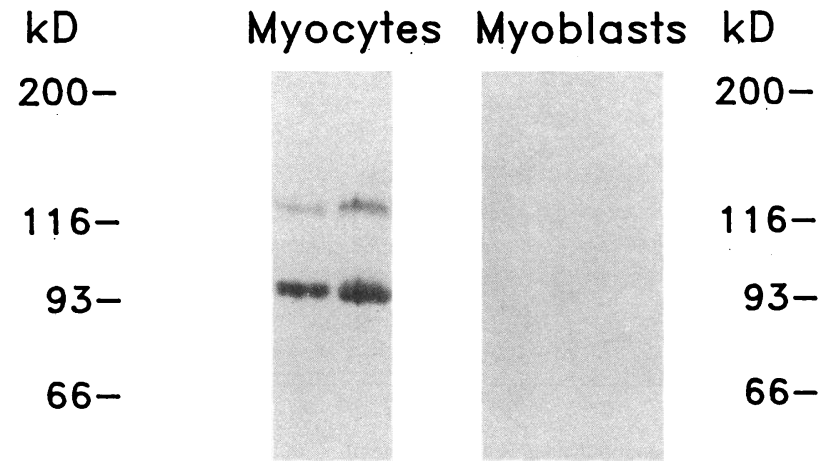

A Bd B8

Bd B8 NHS

B

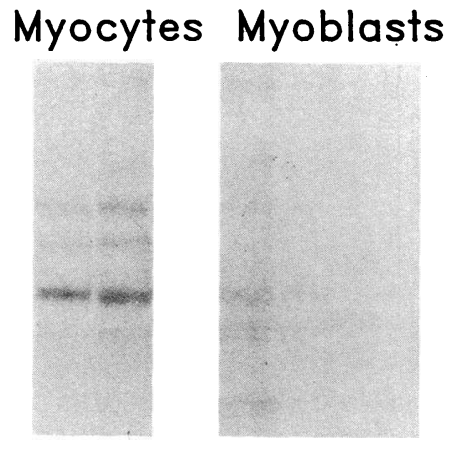

Bd B8
Bd B8 NHS
Figure 7. Biosynthesis of insulin receptors in myoblasts and myocytes in both $(A) \mathrm{BC} 3 \mathrm{H}-1$ and $(B)$ C2 cells. Flasks $\left(75 \mathrm{~cm}^{2}\right)$ of cells were washed twice in PBS. $5 \mathrm{ml}$ of methioninefree medium was added and the pulse commenced by the addition of $1 \mathrm{mCi}$ $\left[{ }^{35}\right.$ S]methionine. After $4 \mathrm{~h}$ of incubation at $37^{\circ} \mathrm{C}$, the cells were then washed with PBS, collected by scraping, and solubilized in $1 \%$ Triton X-100. The insulin re-

ceptor was partially purified over a wheat-germ agglutinin column and immunoprecipitated with either two different polyclonal antireceptor antisera $(B d$ and $B 8)$ or normal human serum $(N H S)$. The immunoprecipitate was then reduced with dithiothreitol, denatured with SDS and subjected to electrophoresis on a denaturating PAGE and autoradiography (24). 
A

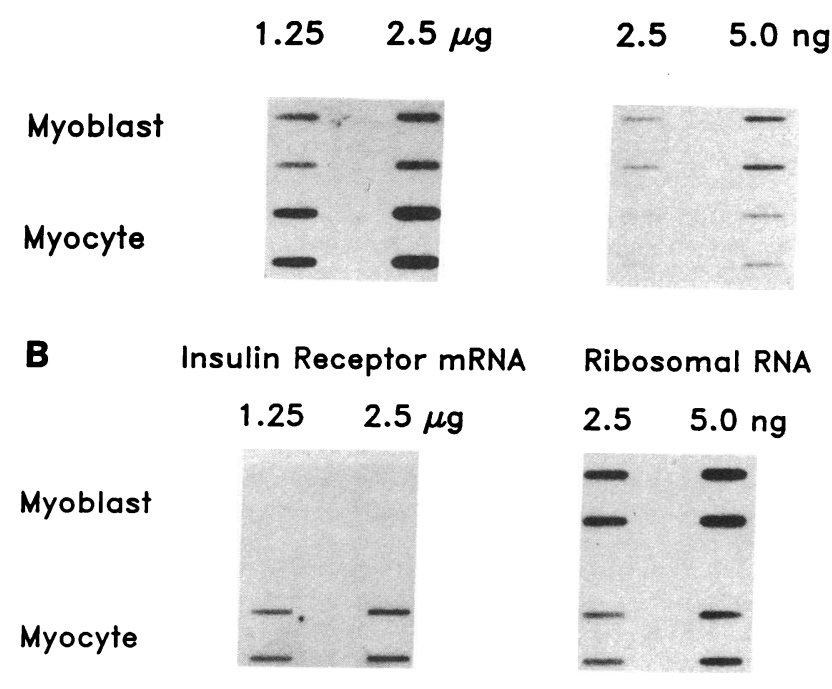

Figure 8. Slot blot analysis of insulin receptor mRNA and ribosomal RNA. Total RNA was isolated from either $(A) \mathrm{BC} 3 \mathrm{H}-1$ or $(B) \mathrm{C} 2$ cells and analyzed in duplicate.

skeletal muscle such as the opposition of the sarcoplasmic reticulum with invaginations of the cell membrane (18). In these cells $\alpha$ actin is of the smooth muscle type. BC3H-1 cells do not fuse after differentiation.

C2 cells were derived from muscle cells of a normal mouse and have the characteristics of skeletal muscle (19). In contrast to $\mathrm{BC} 3 \mathrm{H}-1$ cells, these cells irreversibly fuse after differentiation. In both $\mathrm{BC} 3 \mathrm{H}-1$ and $\mathrm{C} 2$ cells differentiation is accompanied by morphological and biochemical changes $(18,19)$. Typical muscle enzymes and proteins present in normal muscle, such as creatine phosphokinase, myosin and $\alpha$ actin $(14,33$, $34)$, increase during differentiation. Cell surface receptors, such as the nicotinic acetylcholine receptor $(17,35)$, also increase.

In both cell lines, we found that differentiation was associated with an increase in insulin receptor binding. Because $\mathrm{BC} 3 \mathrm{H}-1$ cells had more insulin receptors in the differentiated state than $\mathrm{C} 2$ cells, they were studied more extensively. Several lines of evidence indicated that the increased insulin binding seen after differentiation reflected an increase in receptor biosynthesis. ${ }^{2}$ First, Scatchard analysis and radioimmunoassay indicated an increased receptor content. Secondly, pulse labeling of cellular proteins with $\left.{ }^{35} \mathrm{~S}\right]$ methionine followed by immunoprecipitation with antireceptor antisera indicated that receptor biosynthesis was markedly enhanced. Thirdly, insulin receptor mRNA levels were increased.

The insulin receptor has structural similarity to the IGF-I receptor (32). Since IGF-I receptors were known to be present in $\mathrm{BC} 3 \mathrm{H}-1$ cells, we also examined IGF-I binding in myocytes

2. In BC3H-1 cells it has been reported that after placing differentiated myocytes into media containing high serum concentrations, the cells rapidly dedifferentiate into myoblasts (15). In preliminary studies, we find that $24 \mathrm{~h}$ after placing myocytes into culture medium with $20 \%$ FBS, insulin receptor biosynthesis decreases by $\sim 50 \%$ with a concomitant decrease in ${ }^{125} \mathrm{I}$-insulin binding.

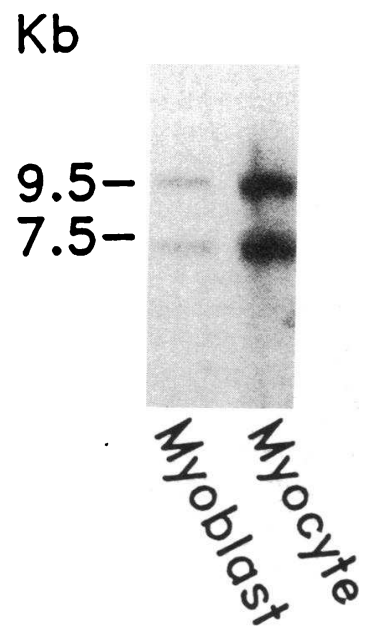

Figure 9. Northern blot analysis of insulin receptor mRNA. Poly $(A)^{+}$RNA was purified from myoblasts and BC3H-1 myocytes and analyzed. An RNA ladder was used for molecular weight standards. and myoblasts both in intact cells and in solubilized receptors. In contrast to insulin receptors (which increased during differentiation), IGF-I receptors were expressed at their highest level in myoblasts and decreased by $50 \%$ after differentiation. Similar changes in insulin and IGF-I receptors were also seen in rat L-6 muscle cells (36). The precise nature of this decrease remains to be established.

To study insulin receptor gene expression, myoblast and myocyte mRNA were isolated and analyzed by both Northern and slot blot analysis. During the terminal differentiation of $\mathrm{BC} 3 \mathrm{H}-1$ and $\mathrm{C} 2$ myoblasts, there was an increase in the levels of insulin receptor mRNA. The molecular mechanism involved in the increase in insulin receptor mRNA accumulation during myogenic differentiation is unknown. Control of insulin receptor mRNA in $\mathrm{BC} 3 \mathrm{H}-1$ and $\mathrm{C} 2$ cells most likely occurs at the level of mRNA transcription, however posttranscriptional processes such as selective mRNA transport from the nucleus or differential mRNA stability (and/or turnover) may also occur. Regulation of muscle gene expression has recently been studied $(35,37)$. With the use of purified cDNA probes, it has been shown that the accumulation of mRNAs for the thick and thin filament proteins of the contractile apparatus is coordinated with myoblast fusion. Studies of gene transcription have suggested that this mRNA accumulation was induced by new mRNA synthesis. Furthermore, studies of acetylcholine receptor expression in C2 myocytes have demonstrated an increase in gene transcription (35).

Muscle tissue is a predominant peripheral site of insulin action and insulin resistance in muscle is a feature of several pathological states including non-insulin-dependent (type II) diabetes mellitus and obesity $(38,39)$. However the in vitro regulation of insulin sensitivity in muscle remains to be studied. Thus, studies of insulin receptor expression during muscle cell differentiation in cell types such as those used herein may be useful in providing insights into the development of insulin resistance in these and other pathological states.

\section{Acknowledgments}

This work was supported by National Institutes of Health grant DK-26667, the Juvenile Diabetes Foundation, and the Elise Stern Haas Fund and the Department of Medicine at Mount Zion Hospital and Medical Center. 


\section{References}

1. Levine, R., M. Goldstein, S. Klein, and B. Huddleston. 1949. The action of insulin on the distribution of galactose in eviscerated nephrectomized dogs. J. Biol. Chem. 179:985-986.

2. Goldfine, I. D. 1981. Effects of insulin on intracellular functions. In Biochemical Actions of Hormones. Volume 8. G. Litwack, editor. Academic Press, Inc., New York. 272-305.

3. Goldfine, I. D. 1987. The insulin receptor: molecular biology and transmembrane signaling. Endocr. Rev. 8:235-255.

4. Kahn, C. R. 1985. The molecular mechanisms of insulin action. Annu. Rev. Med. 36:429-451.

5. Czech, M. P. 1985. The nature and regulation of the insulin receptor: structure and function. Annu. Rev. Physiol. 47:357-381.

6. Jacobs, S., and P. Cuatrecasas. 1981. Insulin receptor: structure and function. Endocr. Rev. 2:251.

7. Ullrich, A., J. R. Bell, E. Y. Chen, R. Herrera, L. M. Petruzzelli, T. J. Dull, P. A. Gray, L. Coussens, Y. C. Lia, M. Tsubokawa, A. Mason, P. H. Seeburg, C. Grundeld, O. M. Rosen, and J. Ramachandran. 1985. Human insulin receptor and its relationship to the tyrosine kinase family of oncogenes. Nature (Lond.). 313:756-761.

8. Ebina, Y., L. Ellis, K. Jarnagin, M. Edery, L. Graf, E. Clauser, J. Ou, F. Masiarz, Y. W. Kahn, I. D. Goldfine, R. A. Roth, and W. J. Rutter. 1985. The human insulin receptor cDNA: the structural basis for hormone-activated transmembrane signalling. Cell. 40:747-758.

9. Olefsky, J. M. 1980. Insulin resistance and insulin action. An in vitro and in vivo perspective. Diabetes. 30:148-162.

10. Goldstein, B. J., D. Muller-Wieland, and C. R. Kahn. 1987. Variation in insulin receptor messenger ribonucleic acid expression in human and rodent tissues. Mol. Endocrinol. 1:759-766.

11. Goldberg, A. L., S. B. Martel, and M. J. Kushmeric. 1975. In vitro preparations of the diaphragm and other skeletal muscles. Methods Enzymol. 29:89.

12. Standaert, M. L., S. D. Schimmel, and R. J. Pollet. 1984. The development of insulin receptors and responses in the differentiating non-fusing muscle cell line BC3H-1. J. Biol. Chem. 259:2337-2345.

13. Beguinot, F., C. R. Kahn, A. C. Moses, and R. J. Smith. 1986. The development of insulin receptors and responsiveness is an early marker of differentiation in the muscle cell line L6. Endocrinology. 118:446-455.

14. Olson, E. N., K. L. Caldwell, J. I. Gordon, and L. Glaser. 1983. Regulation of creatine phosphokinase expression during differentiation of BC3H-1 cells. J. Biol. Chem. 258:2644-2652.

15. Munson, R., Jr., K. L. Caldwell, and L. Glaser. 1982. Multiple controls for the synthesis of muscle-specific proteins in $\mathrm{BC} 3 \mathrm{H} 1$ cells. $J$. Cell Biol. 93:350-356.

16. Strauch, A. R., and P. A. Rubenstein. 1984. Induction of vascular smooth muscle $\alpha$-isoactin expression in BC3H-1 cells. J. Biol. Chem. 259:3152-3159.

17. Olson, E. N., L. Glaser, J. P. Merlie, and J. Lindstrom. 1984. Expression of acetylcholine receptor $\alpha$-subunit mRNA during differentiation of BC3H-1 muscle cell line. J. Biol. Chem. 259:3330-3336.

18. Schubert, D., A. J. Harris, C. E. Devine, and S. Heinemann. 1974. Characterization of a unique muscle cell line. J. Cell Biol. 61:398-413.

19. Yaffe, D., and O. Saxel. 1977. Serial passaging and differentiation of myogenic cells isolated from dystrophic mouse muscle. Nature (Lond.). 270:725-727.

20. Farese, R. V., D. E. Barnes, J. S. Davis, M. L. Standaert, and R. J. Pollet. 1984. Effects of insulin and protein synthesis inhibitors on phospholipid metabolism, diacylglycerol levels, and pyruvate dehydrogenase activity in BC3H-1 cultured myocytes. J. Biol. Chem. 259:7094-7100.
21. Cooper, D. R., T. S. Konda, M. L. Standaert, J. S. Davis, R. J. Pollet, and R. V. Farese. 1987. Insulin increases membrane and cytosolic protein kinase activity in BC3H-1 myocytes. J. Biol. Chem. 262:3633-3639.

22. Marshall, S., K. A. Heidenreich, and H. Horikoshi. 1985. Stoichiometric translocation of adipocyte insulin receptors from the cellsurface to the cell-interior. J. Biol. Chem. 260:4128-4135.

23. Goldfine, I. D., B. A. Maddux, K. Y. Wong, V. Pezzino, V. Papa, A. Brunetti, and R. Vigneri. 1987. A sensitive and specific insulin receptor radioimmunoassay. Diabetes. 36:598a. (Abstr.)

24. Forsayeth, J., B. Maddux, and I. D. Goldfine. 1986. Biosynthesis and processing of the human insulin receptor. Diabetes. 35:837846.

25. Chirgwin, J. M., A. E. Przybyla, R. J. McDonald, and W. J. Rutter. 1979. Isolation of biogically active ribonucleic acid from sources enriched in ribonuclease. Biochemistry. 18:5294-5299.

26. Maniatis, T., E. F. Fritsch, and J. Sambrook. 1982. Molecular Cloning: A Laboratory Manual. Cold Spring Harbor Laboratory, Cold Spring Harbor, NY.

27. McDonald, A. R., B. A. Maddux, Y. Okabayashi, K. Y. Wong, D. M. Hawley, C. D. Logsdon, and I. D. Goldfine. 1987. Regulation of insulin receptor mRNA levels by glucocorticoids. Diabetes. 36:779781.

28. Thomas, P. S. 1980 . Hybridization of denatured RNA and small DNA fragments transferred to nitrocellulose. Proc. Natl. Acad. Sci. USA. 77:5201-5202.

29. Shaw, D. J., and G. I. Bell. 1985. Rsal polymorphism at the insulin receptor locus (INSR) on chromosome 19. Nucleic Acids Res. 13:8659-8661.

30. Fluke, M., K. J. Dennis, and H. Bush. 1981. Characterization of cloned rat ribosomal DNA fragments. Mol. Gen. Genet. 182:25-30.

31. Cleveland, D. W., M. A. Lopata, R. A. MacDonald, N. J. Cowan, W. J. Rutter, and M. W. Kirschner. 1980. Number and evolutionary conservation of alpha and beta-tubulin and cytoplasmic beta and gamma-actin genes using specific cloned cDNA probes. Cell. 20:95-105.

32. Rechler, M. M., and S. P. Nissley. 1985. The nature and regulation of the receptors for insulin-like growth factors. Annu. Rev. Physiol. 47:425-442.

33. Strauch, A. R., J. D. Offord, R. Chalkley, and P. A. Rubenstein. 1986. Characterization of actin mRNA levels during $\mathrm{BC} 3 \mathrm{H} 1$ cell differentiation. J. Biol. Chem. 261:849-855.

34. Medford, R. M., R. M. Wydro, H. T. Nguyen, and B. NadalGinard. 1980. Cytoplasmic processing of myosin heavy chain messenger RNA: evidence provided by using a recombinant DNA plasmid. Proc. Natl. Acad. Sci. USA. 77:5749-5753.

35. Buonanno, A., and J. P. Merlie. 1986. Transcriptional regulation of nicotinic acetylcholine receptor genes during muscle development. J. Biol. Chem. 261:11452-11455.

36. Beguinot, F., C. R. Kahn, A. C. Moses, and R. J. Smith. 1985 Distinct biologically active receptors for insulin, insulin-like growth factor I, and insulin-like growth factor II in cultured skeletal muscle cells. J. Biol. Chem. 260:15892-15998.

37. Hastings, K. E. M., and C. P. Emerson. 1982. cDNA clone analysis of six co-regulated mRNAs encoding skeletal muscle contractile proteins. Proc. Natl. Acad. Sci. USA. 79:1553-1557.

38. DeFronzo, R. A., E. Ferrannini, R. Hendler, P. Felig, J. Wahren. 1983. Regulation of splanchnic and peripheral glucose uptake by insulin and hyperglycemia in man. Diabetes. 32:35-45.

39. Reaven, G. M. 1984. Insulin secretion and insulin action in non-insulin-dependent diabetes mellitus: which defect is primary? Diabetes Care. 7:17. 